\title{
Incremental Change, Transition or Transformation? Optimising Change Pathways for Climate Adaptation in Spatial Planning
}

\section{Rob Roggema ${ }^{1,2,3, *}$, Tim Vermeend ${ }^{4}$ and Andy van den Dobbelsteen ${ }^{2}$}

1 Swinburne University, Institute for Social Research, P.O. Box 218, Hawthorn, VIC 3122, Australia

2 Delft University of Technology, Faculty of Architecture, P.O. Box 5043, 2600 GA Delft, The Netherlands; E-Mails: r.e.roggema@tudelft.nl (R.R.); a.a.j.f.vandendobbelsteen@tudelft.nl (A.v.d.D.)

3 Wageningen University and Research Centre, P.O. Box 47, 6700 AA Wageningen, The Netherlands; E-Mail: rob.roggema@wur.nl

4 UC Architects, Guyotplein 5, 9712 NX Groningen, The Netherlands; E-Mail: timvermeend@ucarchitects.com

* Author to whom correspondence should be addressed; E-Mails: rob@cittaideale.eu or rroggema@swin.edu.au; Tel.: +61-41-4300054.

Received: 23 July 2012; in revised form: 17 September 2012 / Accepted: 24 September 2012 / Published: 3 October 2012

\begin{abstract}
In order to incorporate climate adaptation in spatial planning change is required, because climate change impacts the way we live. This implies that spatial planning, as the arranger of the spatial organisation and layout needs to be able to support this change. Current spatial planning is not yet well equipped to play this role. In this research article three possible routes to navigate change are explored. Incremental change is seen as a slow process, which modifies the landscape only slightly. Transition is seen as a fluent change towards a new future, which is an improved version of the existing; and transformation is seen as a change towards a future that is fundamentally different from the existing. The three pathways are compared and it is concluded that transformational change offers the best perspective in dealing with uncertain, unexpected and unprecedented futures, such as developing in times of climate change. Therefore, transformation is theoretically further elaborated and it is found that a transformational change to a new system already starts at a time when the existing system still fully operates. The change to a new system (called B in this article) therefore already started and the predecessors of B already existed. These 'B-minuses' of the new system can be found through network analysis, where the
\end{abstract}


most intense and connective nodes are the most likely 'B-minuses'. Alternatively B-minuses can be created through locating the areas where key-nodes and existing infrastructure can be related to existing urban functions. As illustrated in the case-study design, these principles are able to guide the design of a climate proof landscape.

Keywords: spatial planning; climate adaptation; transition; transformation; resilience; complex adaptive systems

\section{Introduction}

In recent works different scholars characterise the current timeframe as turbulent and instable. The Earth system is being pushed outside its 'Holocene range' into the 'Antropocene' [1], there is a looming crisis, which both causes and decreases the solvability of increasing instability [2]. We live in a timeframe of a rapid change, uncertainty [3] and turbulence [4], defined as: "the dynamic properties arise not simply from the interaction of the component organizations, but also from the ground itself. The 'ground' is in motion" [5].

These kinds of typecasts pose "the greatest challenge for research and policy ever to confront humanity" [6], major changes of current systems are necessary [7] and as a consequence, there is a need for novel and adaptive governance approaches at the global, regional and local scale [8-10].

Regarding climate change, and beyond 'solving' the climate crisis, adaptation of our societies is necessary and a broad spectrum of adaptation types, such as regulations, financing, adjusted procedures, as well as in spatial planning is required. Adaptation to climate change implies change from the current to an adapted situation. This change can occur in different ways: gradual and incremental, through a transition or in the form of a transformation. This article will examine the different possibilities to enhance the required change, develops a preferred pathway and applies this pathway in a case study.

\section{Research Approach}

\subsection{Research Context}

In most Western societies the political-administrative system claims the power over decision-making in spatial planning issues. The majority of these decisions focus on, but are not limited to, the shorter term and tame problems [11]. This implies that change is incremental and at slower paces. However, if problems are wicked [12], such as for instance climate change [13-15], other types of change are required. These wicked problems may cause events occurring which are unprecedented and surprising. An incremental change in the spatial lay out of an area is then not fast enough to deal with the consequences or anticipate these unpredictable events. In this article these types of change are formulated as pathways towards a new spatial system (e.g. lay-out) that is capable of accommodating these unforeseen future events and impacts. A pathway is in the context of this article seen as a way towards this new spatial system for specific wicked issues, 
in this case climate change. Hence it is not a general pathway that needs to be applied for an entire society or for all aspects within a society. There are still many aspects and spatial elements that will function very well while undergoing incremental changes. The pathways that describe change in a different way are transition and transformational pathways. Decision makers, e.g. politicians in the political administrative system, have the ability to decide to choose the appropriate instruments and tools to achieve these transition and transformational pathways, but only for those issues that require those kinds of transitional or transformational change (e.g. wicked problems). In spatial planning terms these instruments and tools go beyond the traditional zoning plans, which mainly enforce incremental changes. Other instruments, capable of initiating change, are required. Examples of these more incentive based instruments are financial, regulatory or spatial interventions. These function as the signals (early warning or created) that will be discussed in paragraph six. After implementing these incentive based instruments and tools they can become, spatially translated and designed, part of the regular zoning plans.

This article focuses on specific elements of society. It emphasises the relationship between the more severe and unexpected impacts of climate change and the way these impacts can be dealt with through spatial planning. The question answered is how our spatial layout can be adjusted in a way that it can become more adjustable, anticipative and prepared for unexpected change. Our planning processes need to aim to define the future spatial system that is capable of accommodating these future impacts. This requires change in a more fundamental way than current planning can do. As mentioned, this article focuses on the impacts of climate change. However, other wicked problems or significant change can be dealt with using the same methodology. Demographic developments and also economic change usually change in a more predictable way. Change in the population, except maybe for migration, can be very well predicted and economic change, except for the Global Financial Crisis, is well planned for and predictable, in Western countries for instance at a development pace of around two percent. The art of anticipation must therefore focus of these unpredictable aspects of the demographic and economic change and it needs t9o identify the "announcers", the B-minuses (see paragraph five) of change.

\subsection{Problem Statement}

Climate change will impact our spatial layout. Severe and unpredictable events, such as floods, cyclones, droughts or bushfires impact the places where and the way we live. Climate change is, as mentioned before, seen as a wicked problem, causing unexpected, uncertain and unprecedented impacts and events. In the context of this article the focus lies on events that come as a surprise and are categorised as the more severe hazards. The more predictable impacts of climate change can be dealt with in regular planning processes, as they only require minor and incremental changes in the spatial layout. This implies change, ranging from small adjustments to fundamental adaptation. Because these impacts can happen at very short notice, but may also take decades to develop it is important to be 'always prepared'. In order to accommodate these changes in spatial planning, spatial transformations need to be implemented. Current spatial planning practice is very well equipped to accommodate incremental change and in some examples transitions, but is badly prepared for transformations. At a certain time dimension it is easy to enforce change, such as in periods when an area undergoes 
urban developments, or when large reclamations, peat depletions or land consolidations take place in rural landscapes. After these changes have taken place the spatial patterns remain unchanged for many years.

In the Dutch context, most of the land use in the countryside is fixed, supported as it is by land use planning, which ensures in most situations unchanged use for the occupants. Only in case of national importance (such as railway lines, major infrastructure or national safety) the national government can enforce changes. In this context adaptation of spatial patterns is difficult.

\subsection{Research Objective and Approach}

The objective in this research article is to identify possible pathways that might enable spatial adaptation and develop and test the most suitable theoretical approach. The research question is therefore the following: What is the most optimal 'change' pathway, enhancing adaptation to climate change in spatial planning? In order to research this question the object of spatial planning is seen as a complex spatial system, which has the features and characteristics of complex adaptive systems. Changes in these systems follow the rules of complexity and this is the reason why transitional and transformational pathways are the focus. These pathways have the ability to increase the adaptive capacity of (spatial) systems and thus improve the anticipative qualities in spatial systems. The research approach is both deductive and inductive. As deductive research approaches emphasise the general theory is developed first, before validation in the form of a (or several) case study is executed. The theoretical concepts of transition and transformation have been explored before the Peat Colony case study was undertaken. However, while elaborating the case study, further theorising took place and the concepts of networks, B-minuses and interventions were developed.

The following five distinctive steps (Figure 1) are distinguished:

1. Analysis of existing change concepts (section three);

2. Comparison of change concepts (section four);

3. Further concept development of the preferred concept. The applied method to intensify theorising, were the so-called pizza debates. These debates consisted of small group sessions providing an iterative process of consecutive brainstorm $\rightarrow$ capture $\rightarrow$ writing $\rightarrow$ brainstorm $\rightarrow$ elaboration $\rightarrow$ capture $\rightarrow$ writing (section five);

4. Spatial identification of key change elements: (1) Early warning signals and (2) Creation of starting points of transformation (section six);

5. Application of the theoretical concept in a case study (section seven). 
Figure 1. Schematic overview of the research process.

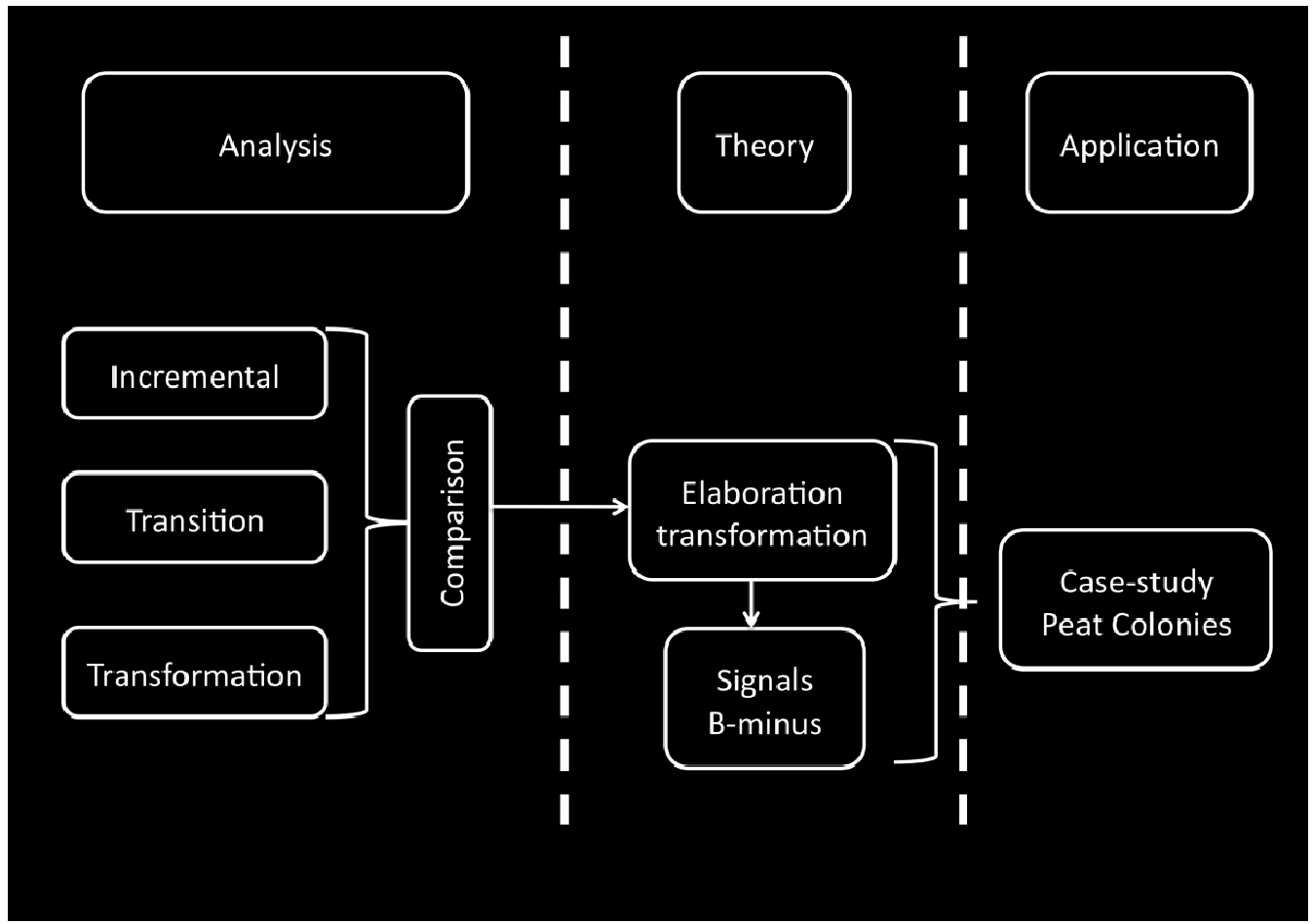

\section{Analysis of Change Processes}

In this section three possible change concepts are analysed: incremental change, transition and transformation. There are many ways change can be looked at. Change can happen independently from actors ('it just occurs'), it can take place as a response or reaction on a certain event (this reactive change is in line with incremental changes) or change is pro-active and anticpating the future, which links more with transitional and transformational change as discussed in this article.

\subsection{Incremental Change}

When the three most recent regional plans for the province of Groningen [16-18] are analysed, changes both in the aims and policies as well as in accompanying functional maps are marginal. Once policies have been defined in the initial plan, they are to a large extent repeated in subsequent plans. When the respective functional maps are measured the repetitive character becomes clear: approximately $2 \%$ of the land area is permitted to change its function over the effective term of the three plans (e.g. 13 years). Despite the fact that there are numerous natural or societal changes occurring in the same spatial area, the spatial planning options to change functions or land-use in the next ten years after a regional plan is adopted, are limited to only $2 \%$ of the area. The Groningen example highlights the 'incrementality' of change and is even more appalling when compared with a preliminary climate adaptive design made for Groningen province, in which approximately $30 \%$ of the land area potentially needs to undergo a functional change [19]. These incremental changes are visualised as a straight but slowly rising line along which the consecutive plans are positioned (Figure 2). 
Figure 2. Subsequent waves of plans of the same 'family'.

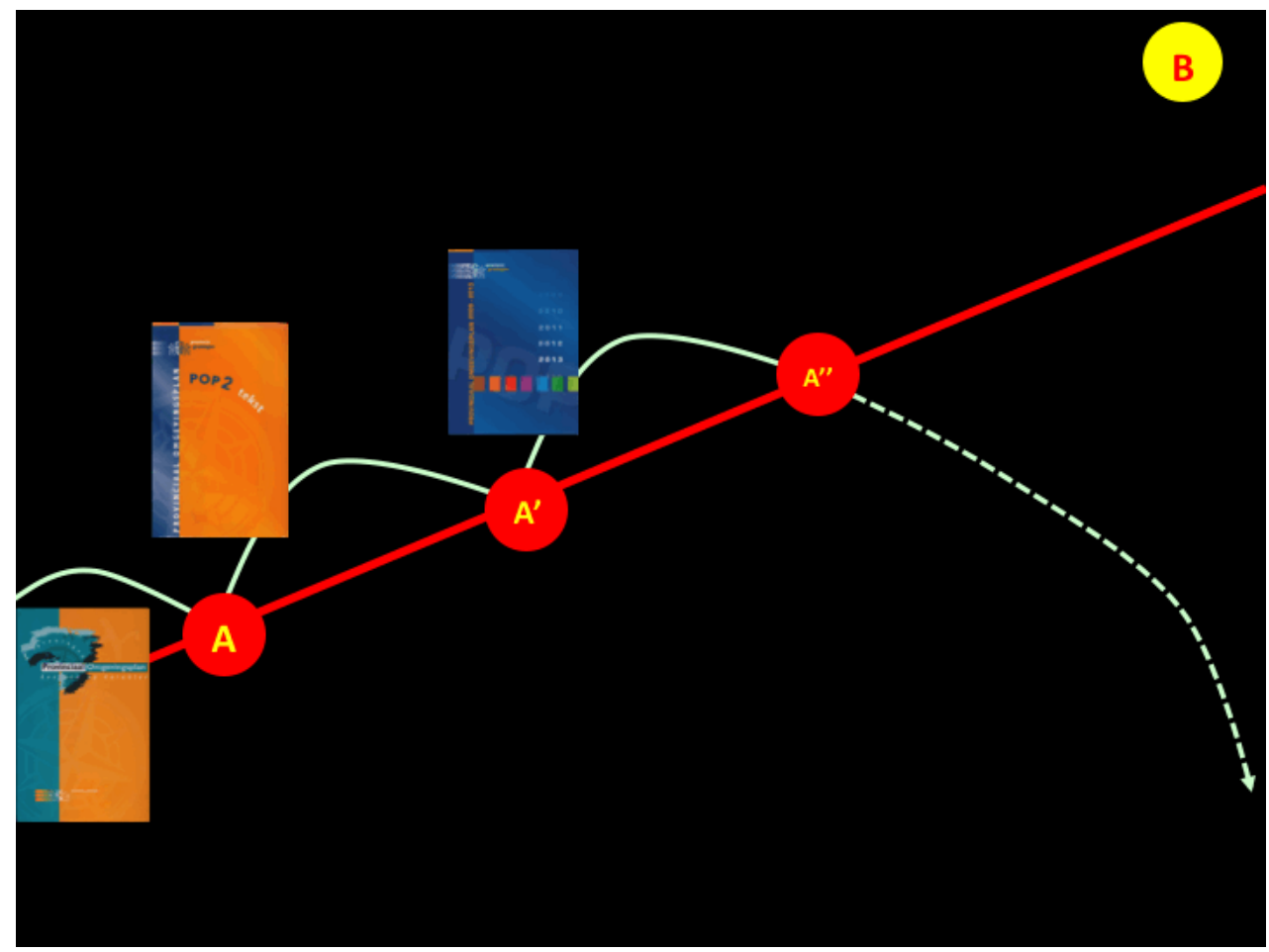

Current planning allows plans to evolve from A to A-apostrophe, while the major changes required emphasise a shift towards B (Figure 2).

\subsection{Transition}

A transition is defined as "a gradual, continuous process of societal change, changing the character of society (or a complex part) structurally" [20]. De Roo [21] attributes dynamics to this change: between two stable phases a dynamic phase enables the system to shift from an old (weak) context towards a new (stronger) one. Various studies on change management demonstrate that this change can only take place if a crisis has been experienced [22-25]. Corresponding schemes all describe this transition as a fluent line up to a certain point where chaotic circumstances appear. Out of this chaos a new fluent line emerges. The fluency of the transition implies that the system itself is not fundamentally transformed. After the transition the same system has reached a new stable state of a higher complexity or quality.

\subsection{Transformation}

Transformation trajectories are the subject of a growing body of literature [26-28]. Folke and colleagues [29] describe a transformation as "the capacity to transform the stability landscape itself in order to become a different kind of system, to create a fundamentally new system when ecological, economic, or social structures make the existing system untenable". Transformation is divided in three phases: preparing, navigating and stabilising [3,7,30]. The moment between preparing and navigating transformation is defined as the window of opportunity, where "the presence of many options a sequence of events yet a short time-frame leading to the start of a transformation". This process is 
called transformation, but it can be questioned if the change described is (limited to) a change of direction within one system instead of a transformation of one system into fundamentally other. Alternatively, transformation is described as disconnected processes of growth ([31], cited in [32,33]): The next 'forming' cycle (phase 1) already starts while the previous 'integrating' stage (phase 3) is still ongoing (Figure 3) [33].

This new forming phase, interfering the existing growth cycle or regime, is initiated through niche innovations, one of the levels that are part of the multi-level perspective [34-36]. The multi-level perspective consists of three analytical levels: niches, (the locus of radical innovations), socio-technical regimes (the locus of established practices and associated rules that stabilise existing systems) and the exogenous socio-technical landscape, representing the nearly unchangeable values and biophysical features. Change starts in niches, where novel configurations appear [34]. The effectiveness of the change, e.g. whether a regime shift (or transformation) will occur, is determined by reinforcements at the regime and/or the landscape level [37]. Hence, this reinforcement determines whether a novelty fails, modifies the regime or transforms the landscape.

The process of transformation consists of several elements (Figure 4). The existing regime is dynamically stable (point 2), which means that it is potentially open for change. However, it will only open up if the pressure from the landscape level creates a window of opportunity (point 1). Both levels then influence externally the niches (point 3,4), which supports the development of novelties (point 5). Once these novelties are developed and are aligned towards a dominant design (point 6), they are capable of breaking through the existing regime (point 7) and enforce adjustments to the old regime, which then will transform into a new regime. Eventually, when the regime shifts are profound, they may influence the landscape level, changing the set of values and/or biophysical properties (point 8).

Figure 3. Overlapping growth cycles [33].

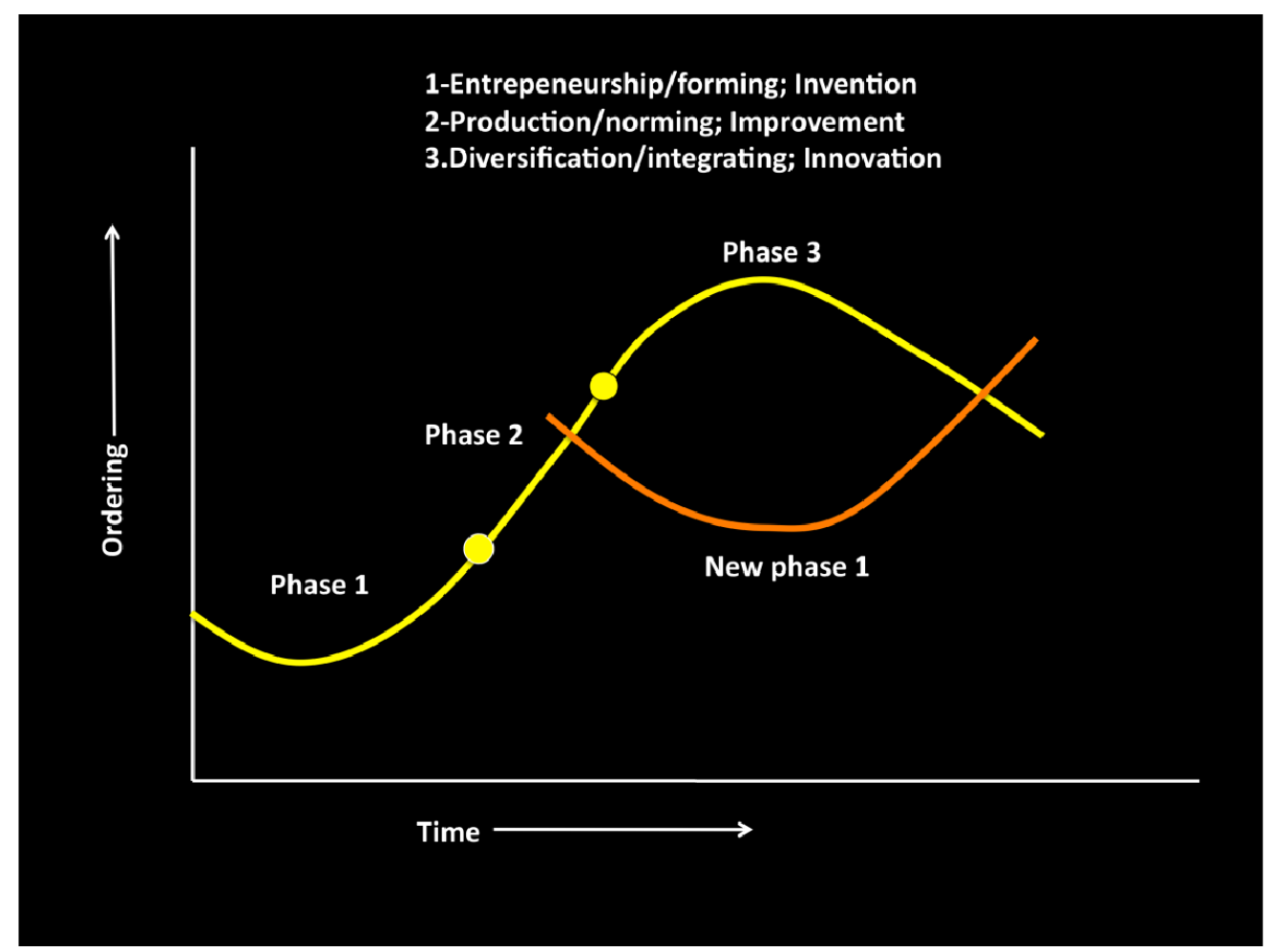


Figure 4. Interaction between the levels of the multi-level perspective [after: 34-36].

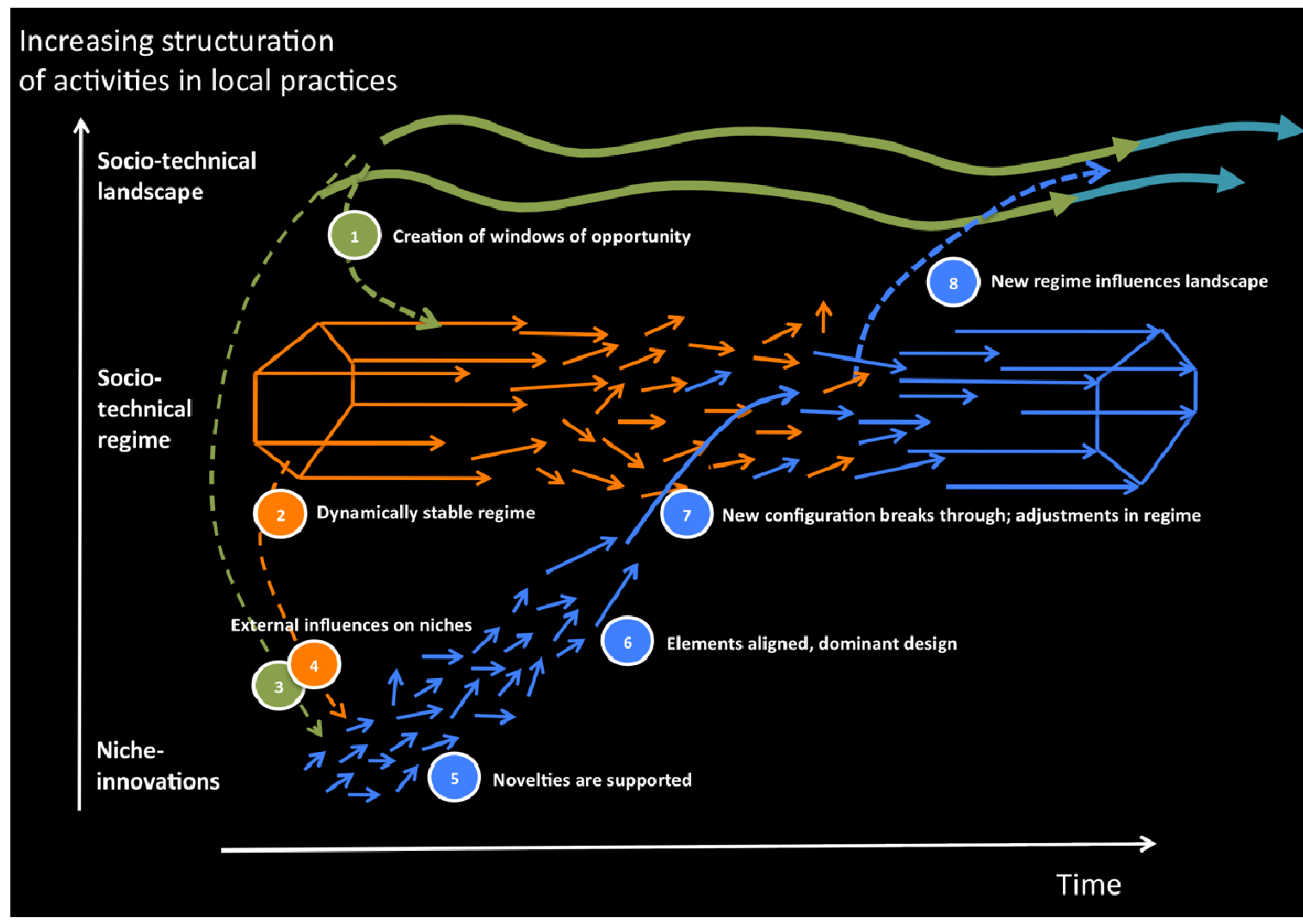

\section{Comparison}

\subsection{Criteria}

The extent to which the processes of change can be used to describe, or enhance, fundamental shifts, depends on the level the following criteria are met:

1. The extent to which the process of change enhances adaptation to climate change in spatial planning;

2. The suitability of describing fundamental change: e.g. a shift from one system to another?

3. The appropriateness to define and achieve a long-term future?

These criteria can be used to review the processes of change and estimate their suitability in enhancing climate adaptation in spatial planning.

\subsection{Comparison}

In order to compare the three pathways of change they are judged against the criteria mentioned above.

a. Enhancing adaptation in spatial planning. All three pathways can enhance climate adaptation in spatial planning. However, incremental change does offer the least potential to do so, because this process leans most to existing habits, decision-making and current policies. Hence, in spatial planning changes are less elaborated and the spatial patterns are to a large extent similar 
to what had been realised in recent history. The transition pathway aims to change from a current state of the system to a future, climate adaptive, one. Hence it offers a good pathway to enhance climate adaptation. It depends on the magnitude of required change if transition pathways are suitable enough to reach this required change. When the change is expected to be more rigorous, the existing system needs to be able to transform into another, better equipped system. In that case, the transformation pathway is more suitable;

b. Fundamental change. When a serious change is expected to happen, or is required to meet future change, the existing spatial patterns must be able to transform in something new that is capable of dealing with those changes and become resilient. A transformational pathway, implying systems change, seems to be the most likely pathway to be satisfying, because this process aims to change existing patterns in something else, becoming prepared for the new demands. To a lesser extent transition pathways allow for change, but in less fundamental ways as the system remains the same while transitioning to a better version. Incremental change is the least suitable process, as it focuses on little changes that are in general not fundamental;

c. Long-term future. Incremental change, transitions and transformations offer the possibility to identify long-term desired futures. In many of the regular spatial plans, focusing on incremental change, such a long-term perspective is defined. However, in the wake of all kinds of practicalities this ambitious future becomes out of sight as soon as practical political decisions need to be made. In transitional as well as transformational processes this long-term desired future is conditional. Without a sound idea about a desired future, transition and transformation are not useful, because it is unclear where to aim for. The difference between the two relates back to the second criterion: when change is more fundamental, transformation seems to be more suitable.

Based on these criteria a transformational process offers better prerequisites to deal with and achieve more fundamental changes. Many judge estimated climate change as uncertain and assuming future change can become more profound than predicted spatial patterns need to be capable of changing more fundamentally. Therefore, the transformational process will be more elaborately discussed in the following section.

\section{Theorising Transformation}

Assuming that fundamental changes will occur in the future the spatial patterns need to be capable of changing accordingly. Current spatial planning practice, as illustrated before, does, in this regard, not satisfy. The changes that are possible in current plans are too small to allow fundamental change. These kinds of change are only possible after a period of stability, in which satisfaction with current paradigms was dominant. During this period repetitive spatial plans are improved, but remain versions of the same type: they shift from A (the original) towards A-apostrophe and A-double apostrophe. Often, this cycle ends when a political cycle comes to a close. A transformation to $\mathrm{B}$, when a fundamental new type of spatial plan can be conceived, is only possible after ending the cycle and the desired long-term future cannot be reached within the current period (Figure 5).

Therefore, a transformational process better suits change from a current series of spatial plans (A) into a fundamental new configuration (B). As Geels indicates, transformation originates somewhere 
outside the existing regime while the current system is still operating. The start of the 'forming' phase of the growth curve of the new system happens where niche innovations are located. The forming of system B can only take place through novelty development, disconnected from the current stable regime (Figure 6). This system needs to follow its own growth curve of forming, whilst crossing and overtaking the current system when it still operates in its norming and integrating phases. Here, we call the forming phase of the new system (B), B-minus.

B-minus can be reached after a disaster or after a prolonged period of unchanged regime. In both cases transformation is supported when an attractive long-term future is defined. Icons and identity [38], branding [39,40], branding identity [41], or a stickiness factor [42] can play an important role in making the future vision attractive. This attractive new future can only be reached through dynamic planning, as described for climate adaptation by Berger and Chambwera [43]. Only then, high expenses and existing standards can be overcome.

A disaster requiring immediate action disturbs regular policies as these become instantly no longer relevant. An instant a shift from one pathway to another is likely (Figure 7). Hardly visible to regular policy-making, pathway B was already in operation (B-minus) but becomes suddenly interesting, as it enables pathways to recover and provides solutions for the longer term.

The other situation in which opportunities can be found to shift pathways to a new desired system is when a current system slowly fades away, for instance because it does not meet current (political) demands anymore. At a certain point another system takes over (Figure 8), because the new system (B) contains features the current timeframe demands.

The change from the current (A) towards a new system (B) requires a shift in its initial stage, e.g. the pre-phase of B: 'B-minus' (Figure 9). This rudimentary, or 'forming' stage of the new system B contains elements of the new system already, but is far from complete.

In order to anticipate a transformation it is important to recognise or create these predecessors of B. This will be discussed in the following section.

Figure 5. The desired future system defined and 'missed' by consecutive regional plans.

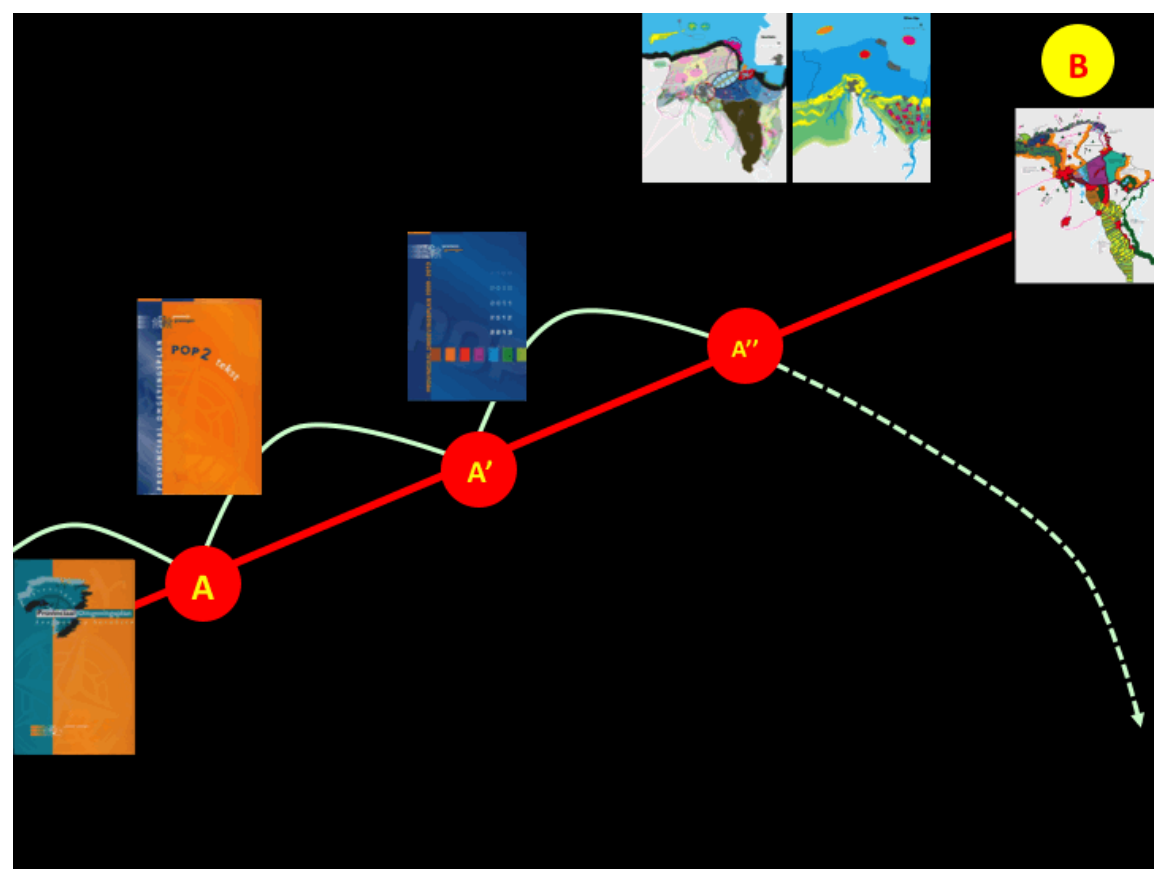


Figure 6. The fluent line of transition changes $\mathrm{A}$ in A-apostrophe, while the shift to B requires a discontinuous process through B-minus.

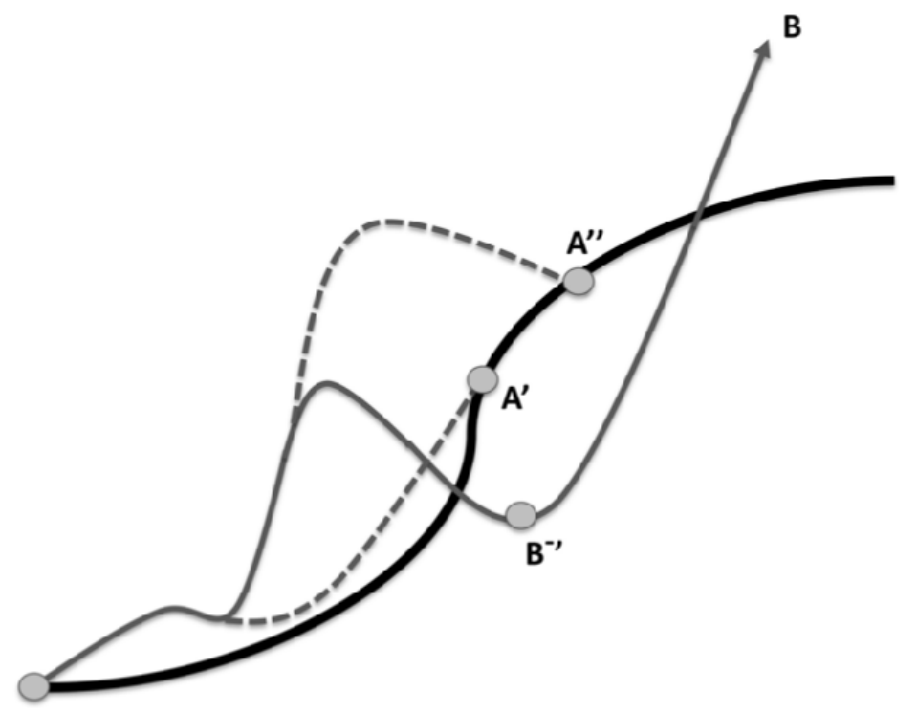

Figure 7. After a disaster pathway B takes over.
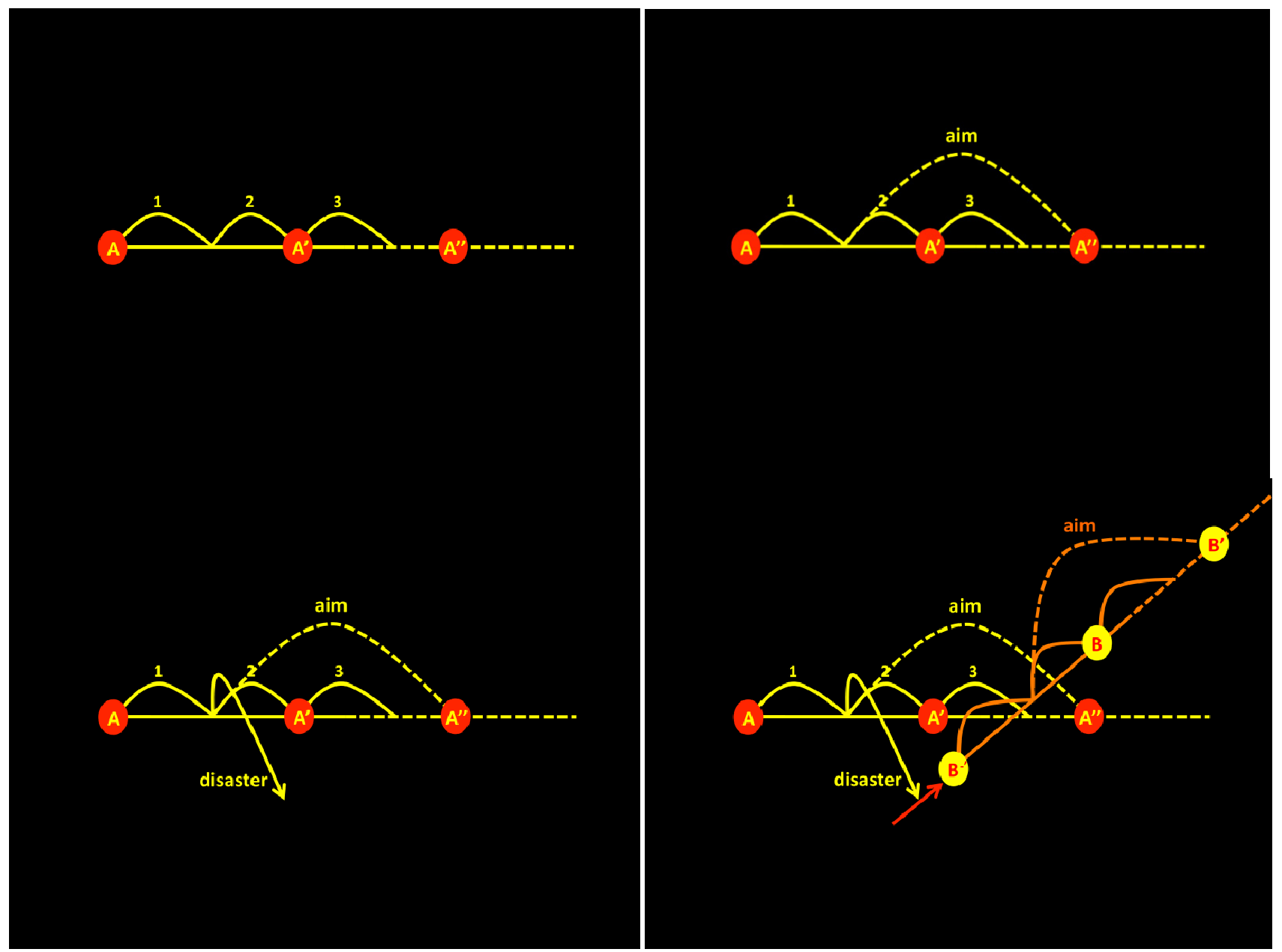
Figure 8. System A fades away and B takes over.
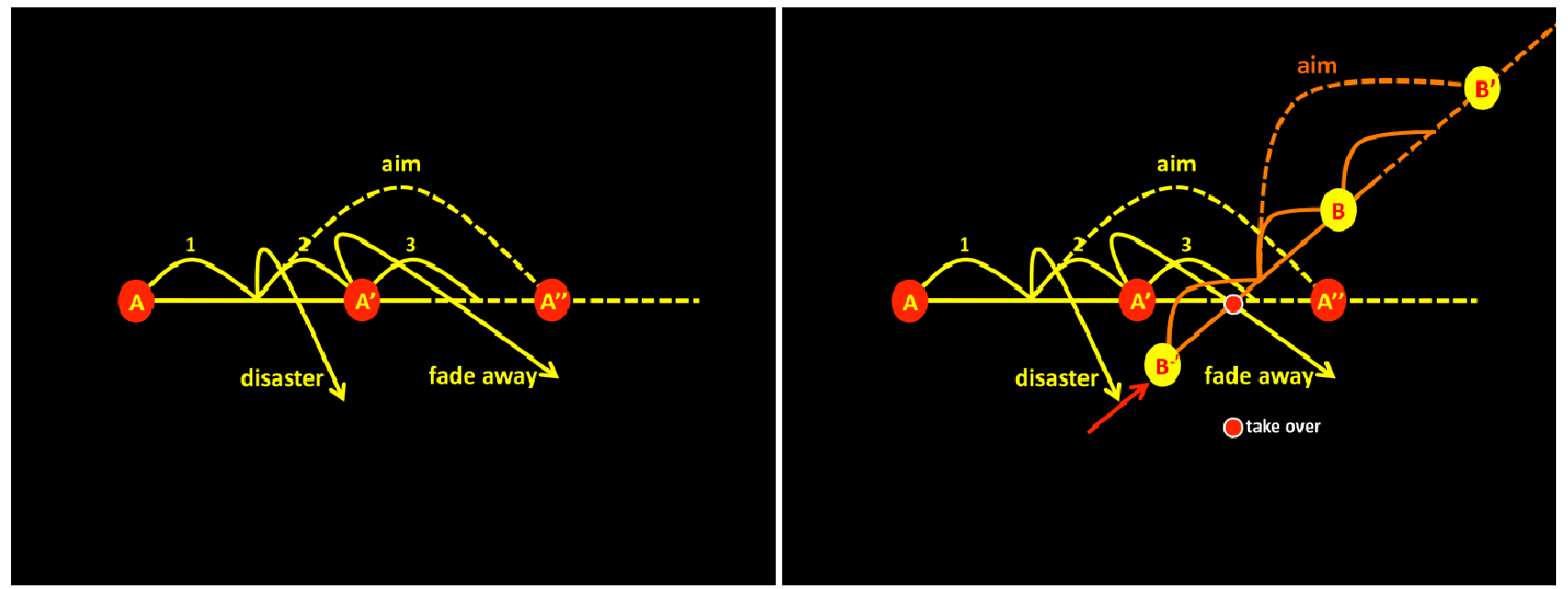

Figure 9. Towards B via B-minus.

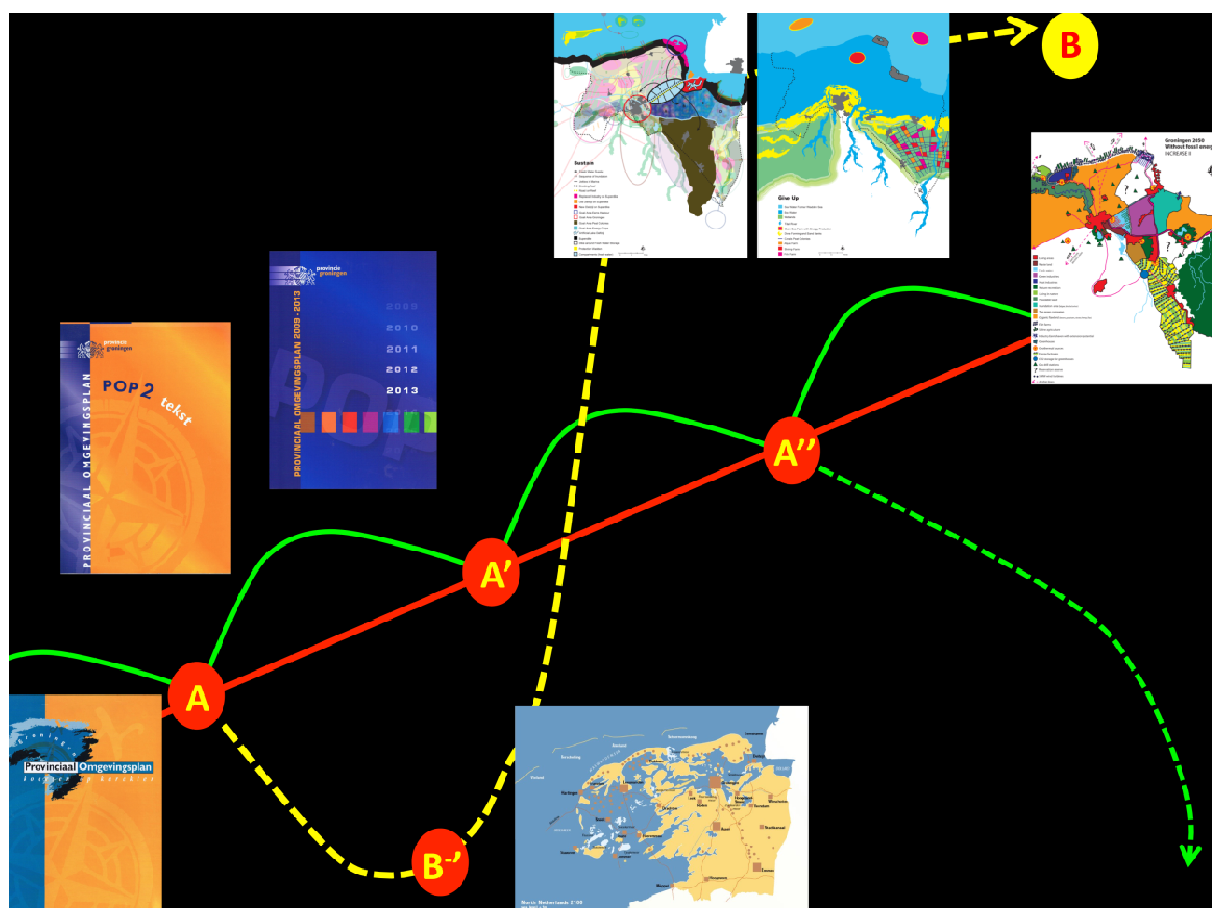

\section{Signals}

Once the attractive future system is defined, it is possible to look for elements of $B$-minus. When a window of opportunity [30] occurs transformation is likely to start and B-minus elements become visible. There are two ways to distinguish the elements of $B$-minus:

1. Observation or active search for signals announcing a transformation, so-called early warning signals [44];

2. The active creation of harbingers of a transformation.

This distinction is used to identify the signals that are apparent or can be developed in a certain context and especially the stronger signals, or outliers, that instigate the start of changes. In planning 
and deciding on a pathway to a future spatial system, this distinction is not relevant, because every trigger that may start a change is valuable as catalyst of the process.

\subsection{Early Warning}

In the work of Scheffer et al. [44], early warning signals are defined for systems approaching a major change. Despite the fact that it is very difficult to develop accurate models to predict thresholds in most complex systems, Scheffer and colleagues discuss the generic character of early warning signals from a range of complex systems. They conclude: "if we have reasons to suspect the possibility of a critical transition, early-warning signals may be a significant step forward when it comes to judging whether the probability of such an event is increasing”. They distinguish the following signals:

1. Critical slowing down: The intrinsic rates of change in the system decrease, leading to a system state that more and more resembles its past state. Two symptoms are distinguished: increase of autocorrelation and increase of variance.

2. Skewness: An unstable equilibrium, which marks the border of the basin of attraction, approaches the attractor from one side. In the vicinity of this unstable point the rates of change are lower. As a result, the system will tend to stay in the vicinity of the unstable point relatively longer.

3. Flickering: The system moves back and forth between the basins of attraction of two alternative attractors.

4. Types of spatial patterns: (1) scale-invariant distributions of patch sizes and increased spatial coherence, or (2) the appearance of regular patterns in systems governed by local disturbances.

These signals not necessarily contain a spatial dimension or make them easy to use or understand in a spatial planning context. However, Table 1 shows a first attempt to 'translate' these signals into possible spatial planning dimensions. No research that we know of aims to unfold early warning signals, announcing a system change, in the spatial domain.

Table 1. Translation of early warning signals into spatial dimensions

\begin{tabular}{ll}
\hline $\begin{array}{l}\text { Announcement of system change (early } \\
\text { warning signals, derived from [39]) }\end{array}$ & Possible translation into spatial dimensions \\
\hline $\begin{array}{l}\text { Critical slowing down (increase of } \\
\text { autocorrelation, increase of variance) }\end{array}$ & $\begin{array}{l}\text { Maintaining old historic structures, re-emphasize existing } \\
\text { patterns of functions } \\
\text { Repetitive policies (the longer policies remain unchanged or } \\
\text { are repeated over and over again, the closer we are to a system } \\
\text { change) }\end{array}$ \\
\hline Skewness & $\begin{array}{l}\text { Dominance of one centre over another, } \\
\text { core- periphery }\end{array}$ \\
\hline $\begin{array}{l}\text { Flickering } \\
\text { Temporarily repetitive occupation for living, temporarily } \\
\text { repetitive flooding }\end{array}$ \\
$\begin{array}{l}\text { sizes/increased spatial coherence } \\
\text { 2. Increase of regular patterns }\end{array}$
\end{tabular}




\subsection{Creation}

Besides trying to identify early warning signals, another option is to actively create starting-points for systems change. Points in networks where developments are likely to start can function as the elements of B-minus. Network theory emphasises that some nodes in networks are more suited for the ignition of change than others. The following key characteristics of networks are derived from Newman et al. [45]:

1. Once enough edges are added, properties of the network suddenly increase in quality [46];

2. Directed networks consist of a core (a giant, strongly connected component), links-in and links-out, as well as other islands and tendrils, represented visually by Broder et al [47] as a bow-tie;

3. The small world effect [48] describes the characteristics of networks: if the number of nodes in the network increases, while connected by a short path, the total length of paths will increase logarithmically and a high level of clustering will occur;

4. The increase of connectivity of nodes in a network depends on the fitness to compete for links [49]. This fitter-gets-richer phenomenon helps to understand the evolution of competitive systems in nature and society;

5. Robust networks are formed by numerously connected nodes, which are highly clustered and know a minimum distance between any random pair [50].

These characteristics have been applied to a concrete spatial situation in preliminary research [51]. In order to determine the points in the network with the greatest potential to start change, the networks were analysed in two steps: (1) the density of individual networks and (2) the number of different network types colliding at one physical location.

The first step examined the density of nodes, defined as: the number of nodes within a grid cell of $10 \times 10 \mathrm{~km}$, combined with their importance. In this case study the importance was weighted on a scale of five (minor element $=1$; mediocre $=3$; and major $=5$ ). The results, in the form of maps for the energy, water and transport network, are shown in Figure 10.

The second step analysed the number of different networks that form a node: one (only water, energy or roads), two (any combination of two) or three (all). When two types collided they were added to the calculation by a factor of 10 and in case of three network types by a factor of 100 . Within each grid cell of $10 \times 10 \mathrm{~km}$, all nodes were calculated and added to a total score per cell.

Finally, the values of individual networks (1) and network types (2) were added to give the total score for each grid cell (Figure 11). Higher scores imply a better starting point for change.

The integrated map illustrates that in this case certain grid cells are more likely to start a system change than others. In the next section identification of these starting points for system change are elaborated in a case study. 
Figure 10. The network maps of water (a); energy (b) and transport (c) [51].

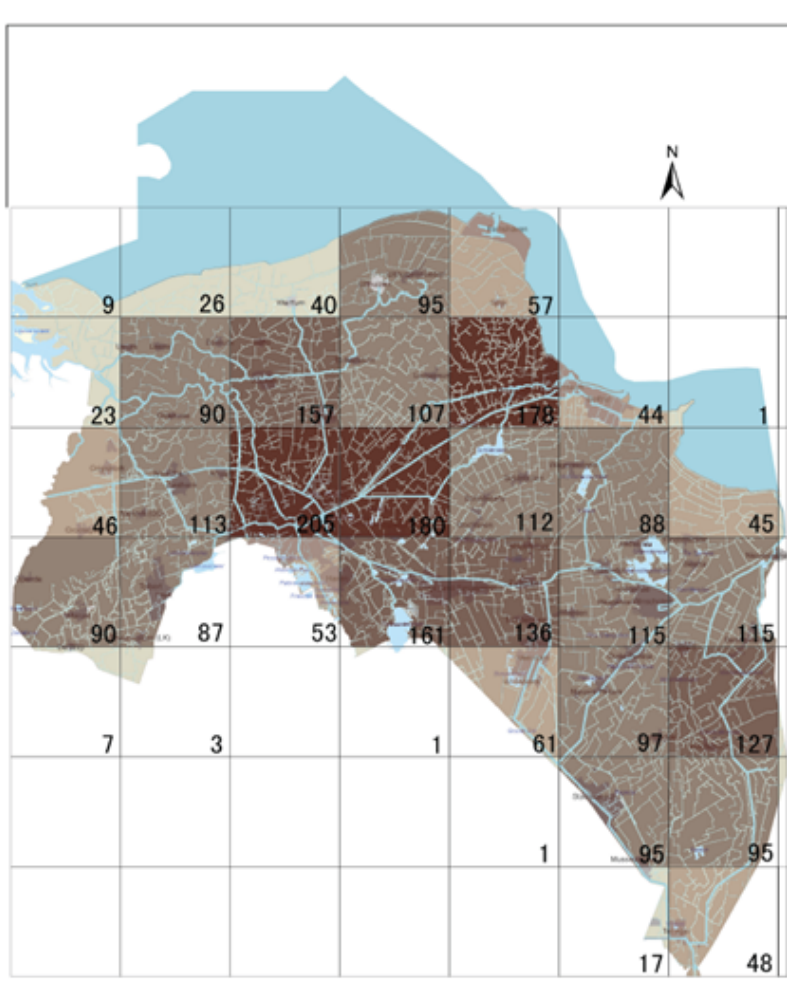

\section{Legend}

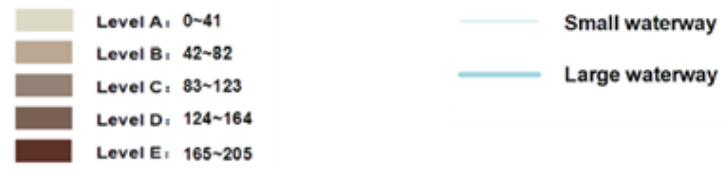

(a)

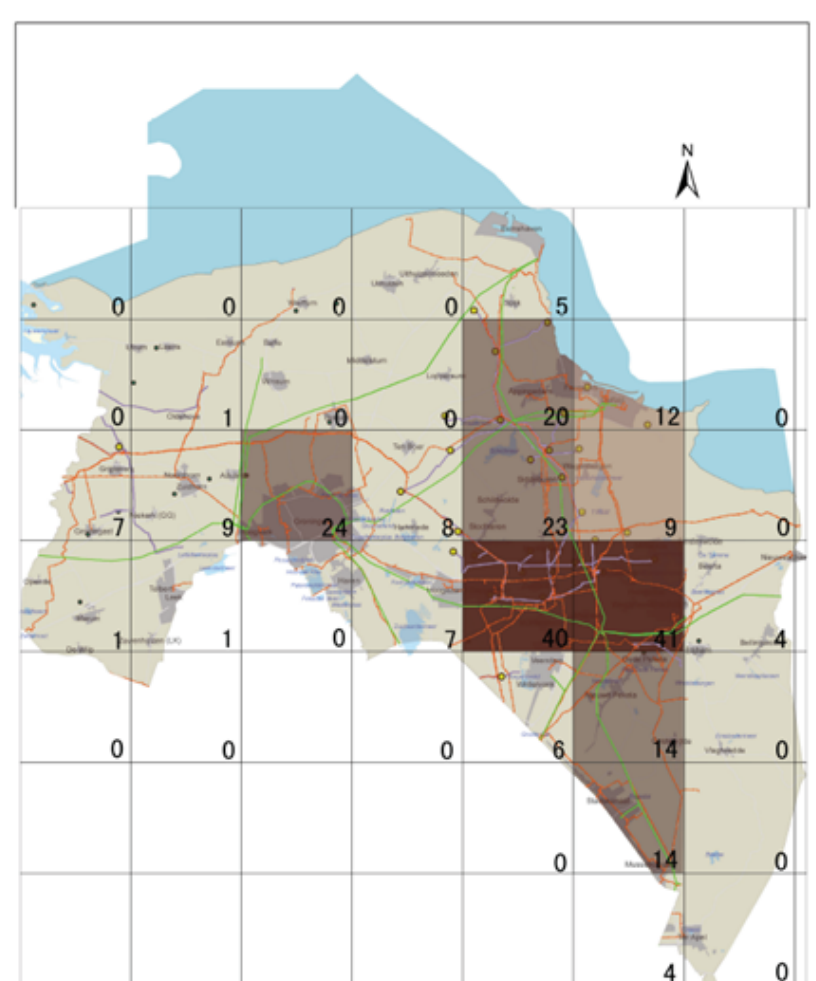

\section{Legend}

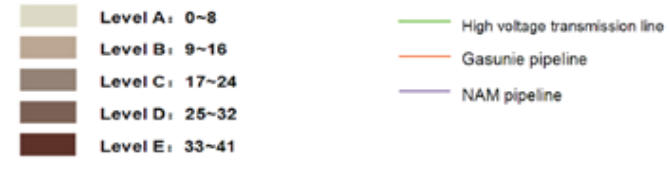

(b)

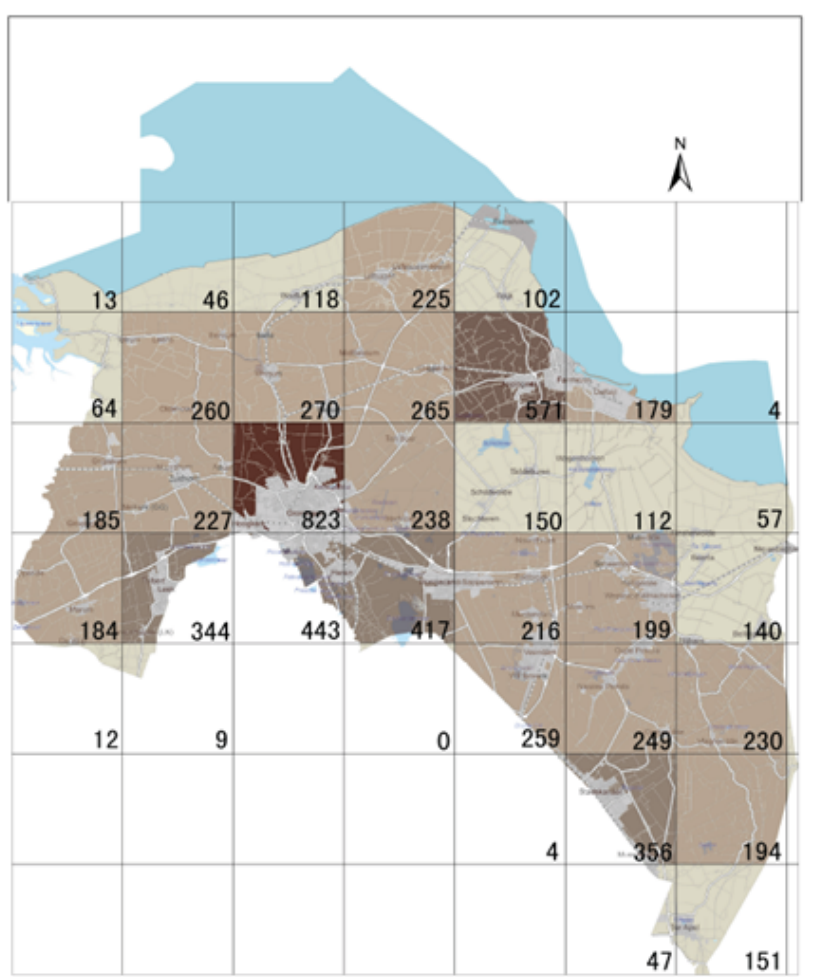

\section{Legend}

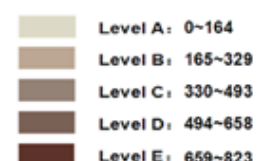

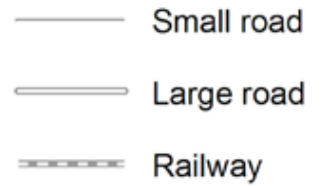

(c) 
Figure 11. Integrated density of networks for Groningen area [51].

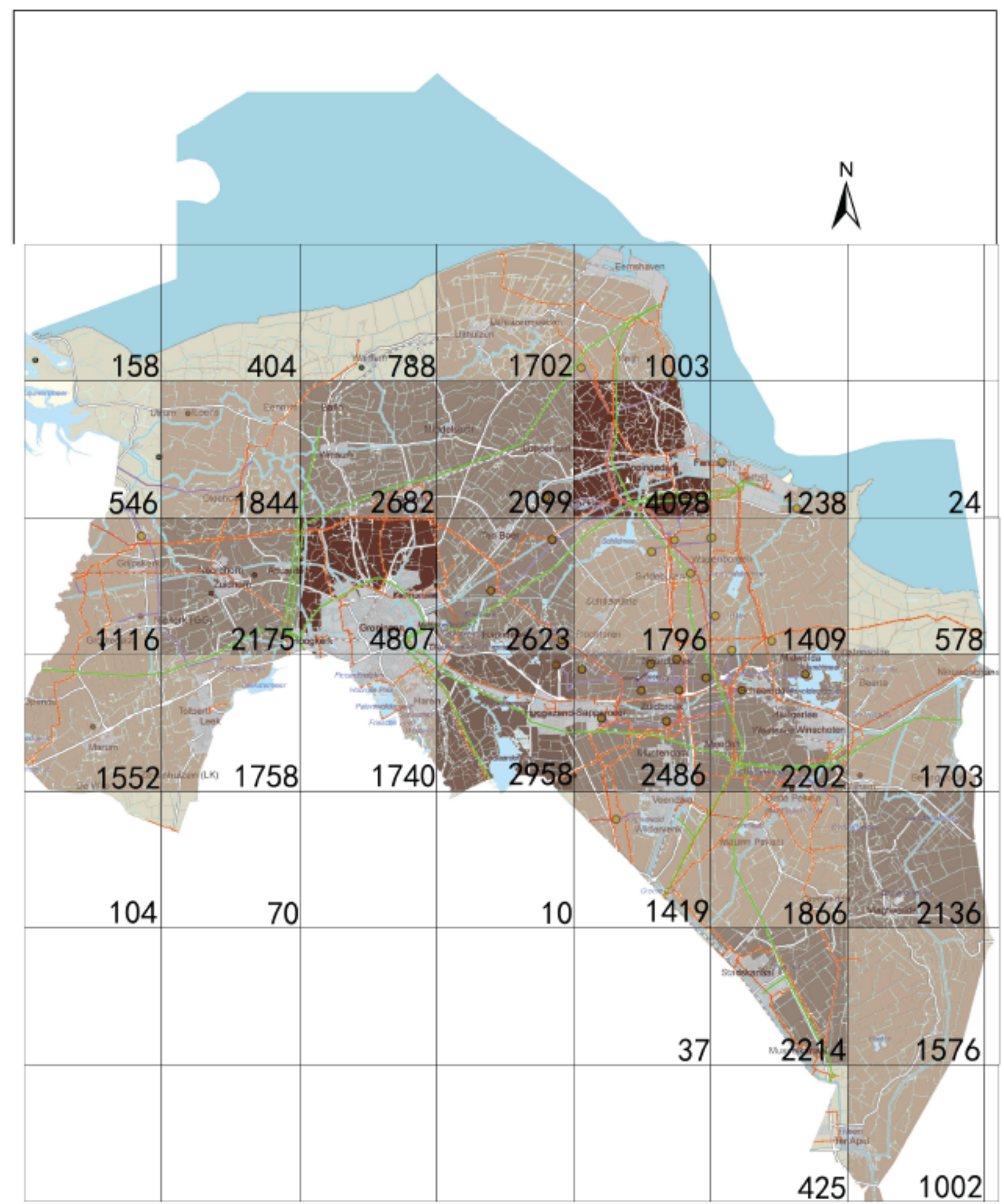

\section{Legend}




\section{Application in the Peat Colonies}

The developed theory of transformation of spatial patterns, as well as the identification of the starting points of change, the B-minuses, has been applied to the case study of the Peat Colonies, an area in the northern part of the Netherlands. The Peat Colonies is an area where in the old days peat was extracted. After this transformation of the peat landscape in a rationalised agricultural area, where orthogonal straight canals and roads dominate, production of potatoes and sugar beets took over. Nowadays the area is confronted with a declining population, marginalised productivity and degrading soil conditions. The application of the developed theory was undertaken in the following steps:

1. Mapping existing networks. Each of the networks, water, energy and transportation were mapped and analysed. The water network consists of a dense pattern of canals and smaller waterways and contains a couple larger canals and natural streams. The energy network is determined by the larger gas- and electricity-grids and their fine mazes, delivering energy to individual homes. The transportation network consists of the main roads and railways and the denser local streets.

2. Identifying 'announcing' nodes. The key nodes in the networks are identified by the density and connectivity of individual nodes. The ones with the densest and connective links are seen as the places where a potential system change might occur. Hence these nodes are identified as the ones that announce an upcoming change. When or how this change will happen is difficult to predict. These nodes are represented on the maps as small circles (Figure 12). These nodes function as announcer 'B-minuses'.

3. Determine 'creation' nodes. The analysis of the networks (e.g. the key nodes) in relation with existing urban (residential, industrial) functions and existing network infrastructure appoints us at areas that are positioned in developmental vicinity. These areas are represented in the maps as ovals (in the transport network) or rectangles in the energy network (Figure 12). Here the nodes can be created that are capable to start transformational change, the creating 'B-minuses'.

4. Climate proof design. The final stage of the application was the use of the identified nodes in the spatial proposal for a climate proof area (Figure 13), in which mitigation and adaptation strategies are combined. The nodes were taken as the directing force for this design. After having identified the key nodes in the networks and the accompanying areas with high developmental potential, the choice for a specific development still needed to be made. Fundamental for this choice has been whether areas are seen as ordinary development areas, e.g. new urban neighbourhoods or economic development zones, or as areas that provide climate adaptation and mitigation contributions. In this case study the choice has been made for the latter option. Among others the following examples are proposed in the design:

- Self-sufficient villages are combined with decentralised large-scale energy generation in the South East. Here the innovative Algae greenhouses are projected as well. A heat-ring is projected to connect these greenhouses with geothermal production areas and transport the heat towards consumers in the larger towns. 
- Two low-lying areas are created for floating algae greenhouses, in combination with storage of surpluses of rainwater. These areas function as the connecting zones of so called 'waterfarms', where water-based agriculture is practiced and clean water is provided, between the eastern and western parts of the Peat Colonies.

- The best-connected nodes in the energy network are used to form the starting points of the heat networks. These isolated areas function in the beginning as solitary elements, but can be connected with each other using the energy network, at a later stage. One big robust heat network emerges.

- Other towns and villages are provided with heat from local supplied renewable energy sources, of which the location is based on the local available renewable energy potentials of heat-generation and storage in the soil.

These spatial elements will start broader developments and emergence of other related functions. The application of the theory in the Peat Colonies illustrates that network analysis provides information about the strategic key nodes in an area, which subsequently can be created as the starting points of development. The fundamental choice to let these locations play a role in mitigating and adapting climate change can provide a transformation in the landscape, which operates as a climate proof landscape. 
Figure 12. Key nodes in the water- (a); energy- (b) and transport network (c).

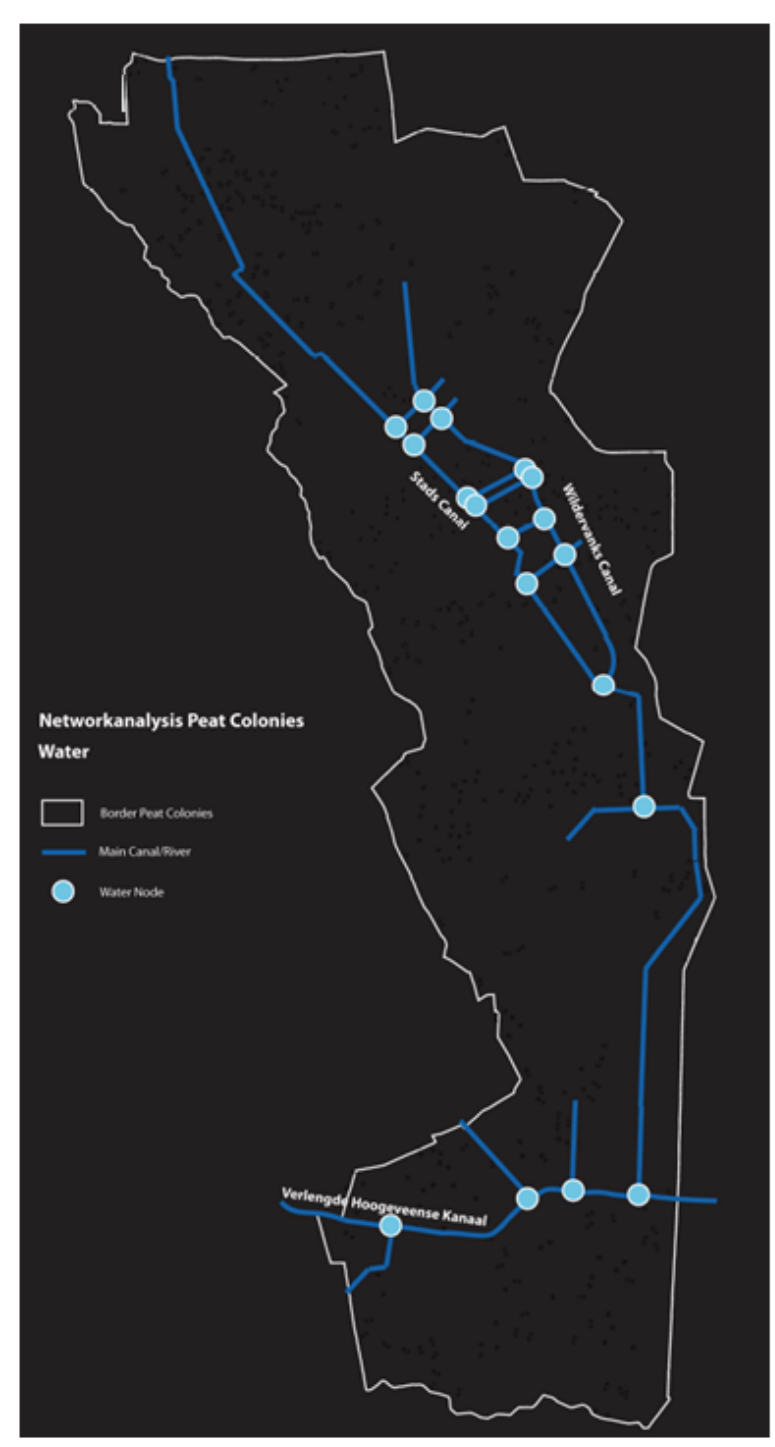

(a)

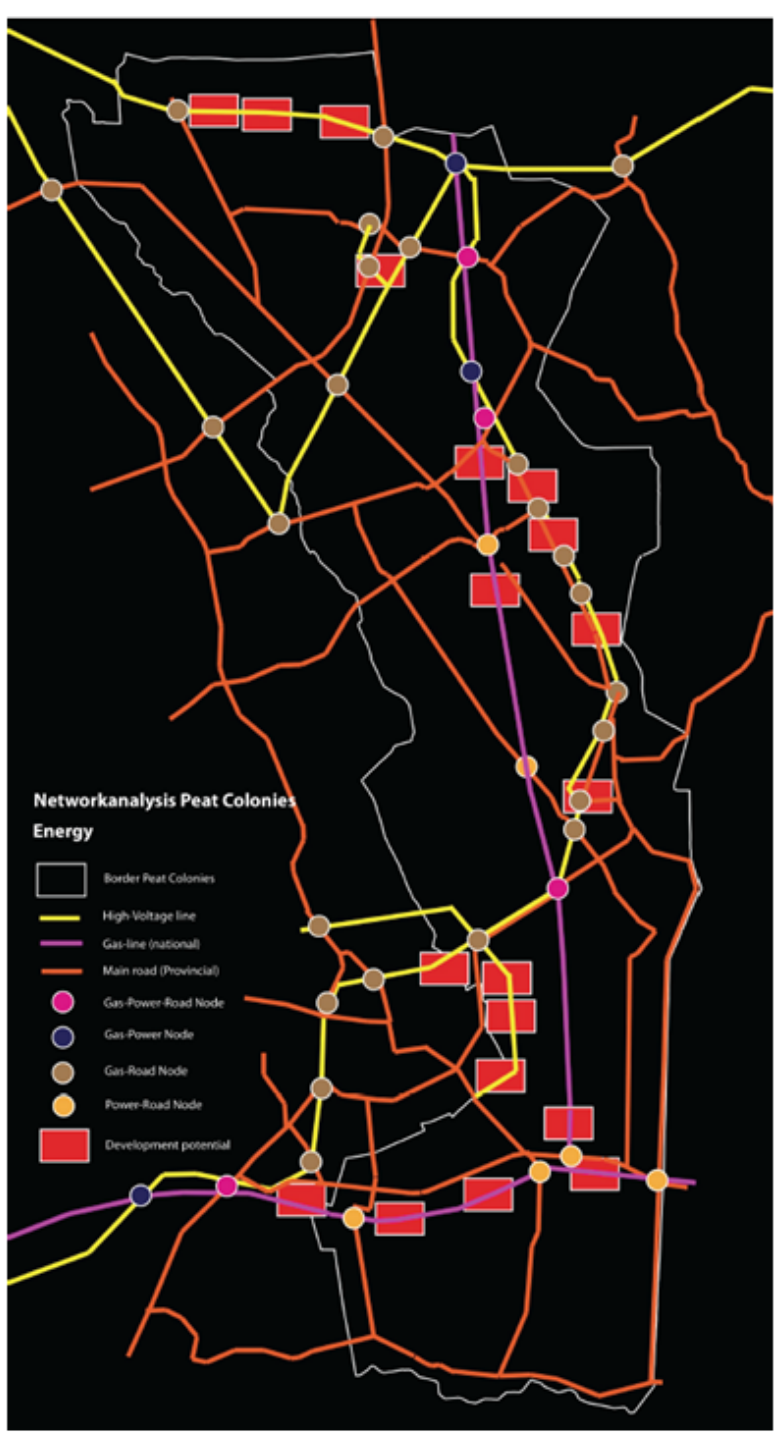

(b)

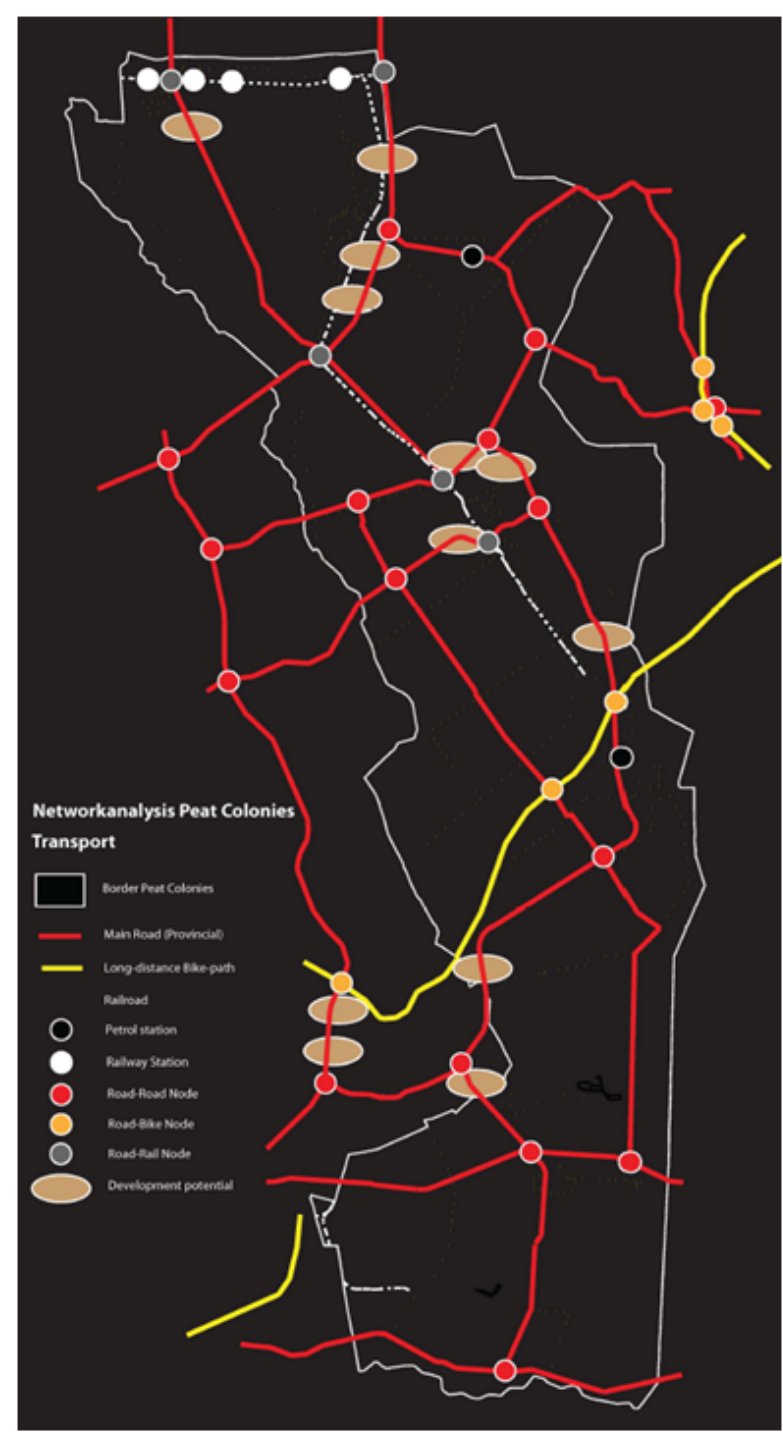

(c) 
Figure 13. Integrated climate adaptive design for the Peat Colonies [52].

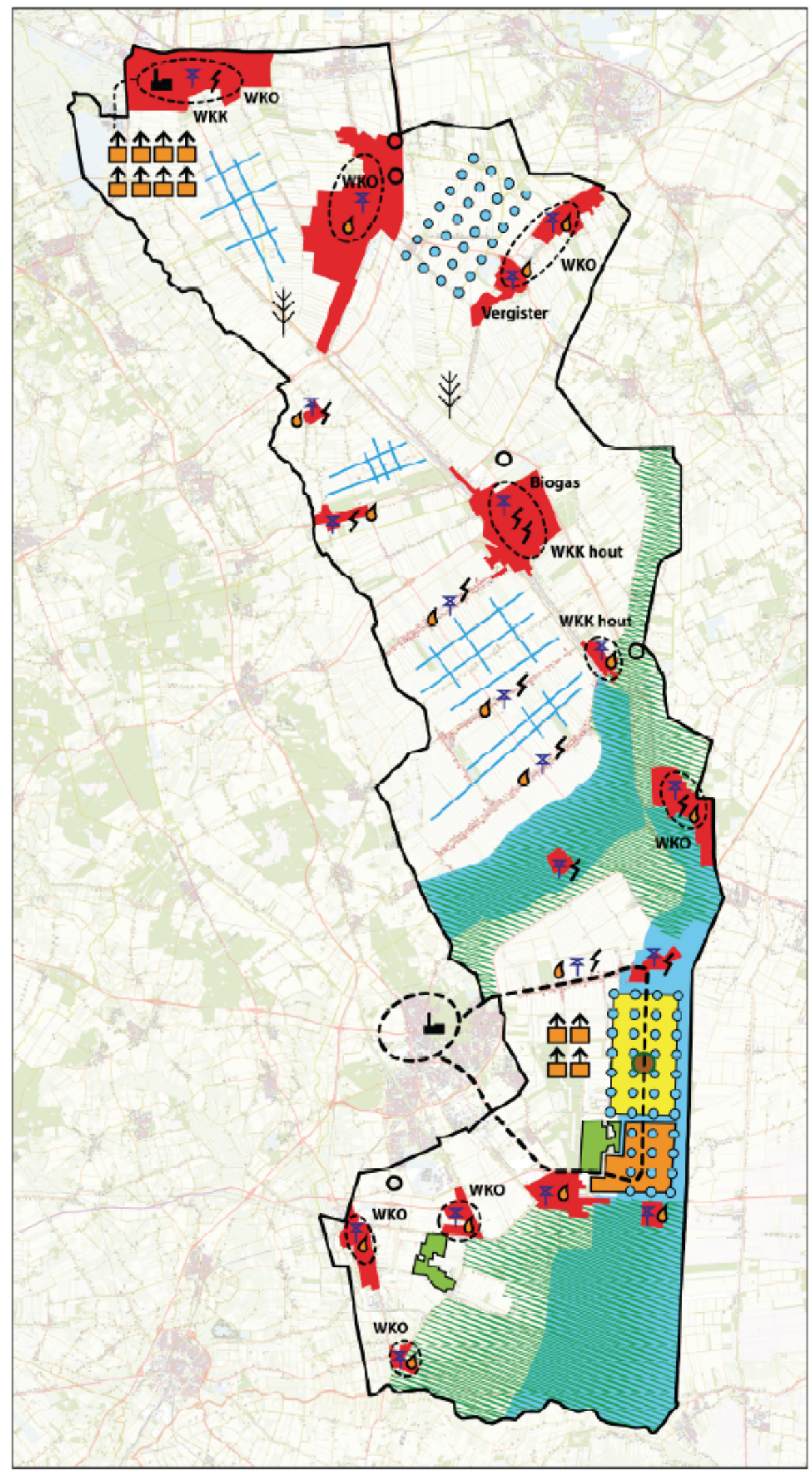

Integrated Energy Vision Peat Colonies

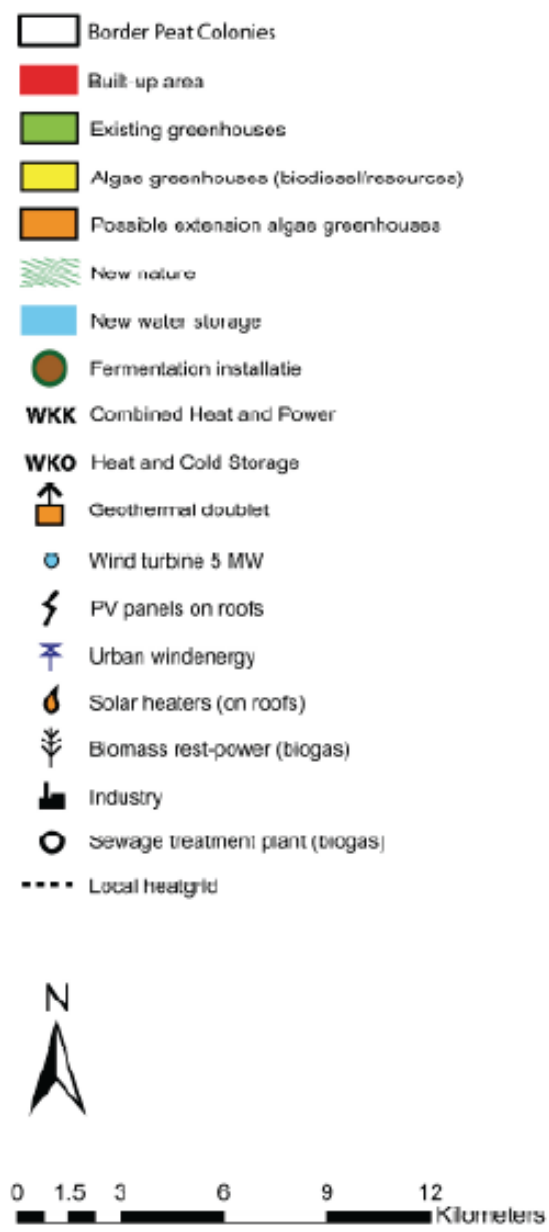




\section{Conclusions}

As presented in this article, current spatial planning has difficulties to incorporate the topic of climate change because it imposes change in the spatial system and the majority of spatial planning trajectories aim for an unchanged or only marginal changed spatial layout. This tension between the need to change the spatial layout as a result of climate change and the inherent characteristic of spatial planning to preserve the layout as it is causes problems on the long term. In principle three pathways describing change can be distinguished: incremental change, transition and transformation. When change is expected to be fundamental and to confront society with the need to change substantial parts of its spatial layout, transformation offers the most suitable description of navigating those changes. In this article it has been concluded that transformation implies the change towards a fundamental new system, which fits with the need to change substantial parts. Therefore transformation is studied in more depth.

A transformation does not happen out of no-where, but it announces itself already while the existing system still operates [33]. In this article we have taken this fact as the starting point and this resulted in the definition of B-minus, the elements that announce or enhance a system change. The search for these elements makes it possible to understand and explain, announce and ignite a transformation. The discovery of B-minuses helps to identify the announcement of a system change and the creation of B-minuses supports a system change.

Early warning systems can be discovered, announcing the approach of a threshold and system change [44]. These early warning signals are found in several types of systems, with exception of spatial systems. The first attempt to define these signals in spatial dimensions has been demonstrated here, but this requires further elaboration.

The other way is to create B-minus elements, which, most likely then start a system change. Learning from network theory, the most intense nodes in networks and the most connected networks are the places where these elements can be estimated to emerge. More elaborate research is required to define these locations in the network more precisely.

The application of the developed theory in the case study of the Peat Colonies illustrates that transformational change can be enhanced on the basis of network analysis, identification of key nodes that announce a potential change and the creation of development locations where key nodes, existing infrastructure and urban functions are related to each other. The way these locations are developed determine whether the area as a whole is transforming towards a climate proof region, as has been illustrated here, or towards other forms of urban development. When the locations are specifically directed in mitigation- or adaptation futures, the entire landscape is most likely to transform in that direction.

In conclusion, the pathways leading to A-apostrophe and B respectively (Table 2) have fundamental different properties. The A-apostrophe pathway is useful to enforce change if tame problems in relatively steady environments are to be dealt with. In this case linear thinking and a transition pathway can be used. However, if a wicked problem must be dealt with and the environment is complex, transformational change and non-linear thinking are more suitable to facilitate change. 
Table 2. Characteristics of pathways leading to respectively A-apostrophe and B-minus.

\begin{tabular}{ll}
\hline A-apostrophe & B-minus \\
\hline Tame problems & Wicked problems \\
Moderate environments & Turbulent environments \\
Transition & Transformation \\
Linear thinking & Non-linear (dynamic) thinking \\
\hline
\end{tabular}

\section{Acknowledgments}

This research was made possible by the contribution of the Dutch Ministry of Housing, Spatial Affairs and the Environment and by support of the Dutch 'Climate Changes Spatial Planning' programme.

\section{Conflict of Interest}

The authors declare no conflict of interest.

\section{References}

1. Steffen, W.; Sanderson, A.; Jäger, J.; Tyson, P.D.; Moore, B., III; Matson, P.A.; Richardson, K.; Oldfield, F.; Schellnhuber, H.-J.; Turner, B.L., II; et al. Global Change and the Earth System: A Planet under Pressure; Springer-Verlag: Heidelberg, Germany, 2004.

2. Walker, B.; Barrett, S.; Polasky, S.; Galaz, V.; Folke, C.; Engström, G.; Ackerman, F.; Arrow, K.; Carpenter, S.; Chopra, S.; et al. Looming global-scale failures and missing institutions. Science 2009, 325, 1345-1346.

3. Chapin, F.S., III; Carpenter, S.R.; Kofinas, G.P.; Folke, C.; Abel, N.; Clark, W.C.; Olsson, P.; Stafford Smith, D.M.; Walker, B.; Young, O.R.; et al. Ecosystem stewardship: Sustainability strategies for a rapidly changing planet. Trends. Ecol. Evol. 2009, 25, 241-249.

4. Business Planning for Turbulent Times: New Methods for Applying Scenarios; Ramirez, R., Selsky, J.W., van der Heijden, K., Eds.; Earthscan Publications Ltd.: London, UK, 2008.

5. Emery, F.E.; Trist, E.L. The causal texture of organizational environments. Hum. Relat. 1965, 18, 21-32.

6. Steffen, W.; Crutzen, P.J.; McNeill, J.R. The Anthropocene: Are humans now overwhelming the great forces of Nature? Ambio. 2007, 36, 614-621.

7. Olsson, P. Navigating transformations in social-ecological systems. Presented at the NCCARFSeminar, Melbourne, Australia, 10 February 2011.

8. Dietz, T.; Ostrom, E.; Stern, P.C. The struggle to govern the commons. Science 2003, 302, 1907-1912.

9. Folke, C.; Hahn, T.; Olsson, P.; Norberg, J. Adaptive governance of social-ecological systems. Ann. Rev. Env. Resour. 2005, 30, 441-473.

10. Berkman, P.A.; Young, O.R. Governance and environmental change in the Arctic Ocean. Science 2009, 324, 339-340. 
11. Conklin, J. Wicked Problems and Social Complexity; CogNexus Institute: Napa, USA; p. 11. Available online: http://cognexus.org/wpf/wickedproblems.pdf (accessed on 13 December 2010).

12. Rittel, H.; Webber, M. Dilemmas in a general theory of planning. Pol. Stud. 1973, 4, $155-69$.

13. Australian Government. Tackling Wicked Problems; A Public Policy Perspective; Australian Public Service Commission: Canberra, Australia, 2007.

14. VROM-raad. De Hype Voorbij, Klimaatverandering Als Structureel Ruimtelijk Vraagstuk, Advies 060; VROM-raad: Den Haag, The Netherlands, 2007

15. Lazarus, R. Super Wicked Problems and Climate Change: Restraining the Present to Liberate the Future; Cornell Law Review; Georgetown Public Law Research: Washington, DC, USA, 2009; pp. 1053-233.

16. Provincie Groningen. Provinciaal Omgevingsplan; Vastgesteld op 14 December 2000; Provincie Groningen: Groningen, The Netherlands, 2000.

17. Provincie Groningen. Provinciaal Omgevingsplan, POP 2 tekst en kaarten; Vastgesteld op 5 Juli 2006; Provincie Groningen: Groningen, The Netherlands, 2000.

18. Provincie Groningen. Provinciaal Omgevingsplan 2009-2013; Vastgesteld op 17 Juni 2009; Provincie Groningen: Groningen, The Netherlands, 2009.

19. Roggema, R. Spatial Impact of the Adaptation to Climate Change in the Province of Groningen, Move with Time; Climate Changes Spatial Planning \& Province of Groningen: Groningen, The Netherlands, 2007.

20. Rotmans, J.; Kemp, R.; van Asselt, M.; Geels, F.; Verbong, G.; Molendijk, K. Transities en Transitiemanagement: De Casus Van Een Emissiearme Energievoorziening; ICIS: Maastricht, The Netherlands, 2000.

21. De Roo, G. A Theory of Transition and its Relevance to Planning Theory and Practice. A Non-Linear Understanding of Spatial Development. In Proceedings of the VIIth meeting of Aesop's Thematic Group on Complexity and Planning, Milano, Italy, 22-23 February 2008.

22. Zuijderhoudt, R. Op Zoek Naar Synergie, Omgaan Met Onoplosbare Problemen, Ph.D. Thesis, University of Amsterdam, Amsterdam, The Netherlands, 2007.

23. Hurst, D.K. Crisis en Vernieuwing: De Uitdaging van Organisativerandering; Scriptum: Schiedam, The Netherlands, 1997.

24. Peters, J.; Wetzels, R. Niets Nieuws Onder de Zon en Andere Toevalligheden, Strategie uit Chaos; Uitgeverij Business Contact: Amsterdam, The Netherlands, 1997.

25. Homan, T. Organisatiedynamica; Sdu uitgevers: Den Haag, The Netherlands, 2005.

26. Panarchy: Understanding Transformations in Human and Natural Systems; Gunderson, L., Holling, C.S., Eds.; Island Press: Washington, DC, USA, 2002.

27. Geels, F.W.; Kemp, R. Transitions, Transformations and Reproduction: Dynamics of Socio-Technical Systems. In Flexibility and Stability in Economic Transformation; McKelvey, M., Holmén, M., Eds.; Oxford University Press: New York, NY, USA, 2006; pp. 227-256.

28. Chapin, F.S., III; McGuire, A.D.; Ruess, R.W.; Hollingsworth, T.N.; Mack, M.C.; Johnstone, J.F.; Kasischke, E.S.; Euskirchen, E.S.; Jones, J.B.; Jorgenson, J.F.; et al. Resilience of Alaska's boreal forest to climatic change. Can. J. Forest Res. 2010, 40, doi: 10.1139/X10-074. 
29. Folke, C.; Carpenter, S.R.; Walker, B.; Scheffer, M.; Chapin, T.; Rockström, J. Resilience thinking: Integrating resilience, adaptability and transformability. Ecol. Soc. 2010, 15, 20. Available online: http:// www.ecologyandsociety.org/vol15/iss4/art20/ (accessed on 15 December 2010).

30. Olsson, P.; Gunderson, L.H.; Carpenter, S.R.; Ryan, P.; Lebel, L.; Folke, C.; Holling, C. Shooting the rapids: Navigating transitions to adaptive governance of social-ecological systems. Ecol. Soc. 2006, 11, 18. Available online: http://www.ecologyandsociety.org/vol11/iss1/art18/ (accessed on 15 December 2010).

31. Perez, C. Technological Revolutions and Financial Capital; Edgar Elgar: Cheltenham, UK, 2002.

32. Blauwhof, G.; Verbaan, W. Wolk 777, Over Crisis, Krimp en Duurzaamheid; Uitgeverij Blauwdruk: Wageningen, The Netherlands, 2009.

33. Ainsworth-Land, G.T. Grow or Die. The Unifying Principle of Transformation; John Wiley \& Sons: New York, NY, USA, 1986.

34. Geels, F.W. Technological transitions as evolutionary reconfiguration processes: A multilevel perspective and a case study. Res. Policy 2002, 31, 1257-1274.

35. Geels, F.W. Processes and patterns in transitions and system innovations: Refining the co-evolutionary multi-level perspective. Technol. Forecast Soc. 2005, 72, 681-696.

36. Geels, F.W. The multi-level perspective on sustainability transitions: Responses to seven criticisms. Technol. Forecast Soc. 2011, 1, 24-40.

37. Kemp, R.; Rip, A.; Schot, J.W. Constructing transition paths through the management of niches. In Path Dependence and Creation; Garud, R., Karnoe, P., Eds.; Lawrence Erlbaum: Mahwah, NJ, USA, 2001; pp. 269-299.

38. Castells, M. The Rise of the Network Society; Blackwell: Oxford, UK, 1996.

39. Franzen, G.; Bouwman, M. De Mentale Wereld van Merken; Samsom: Alphen aan den Rijn, The Netherlands, 1999.

40. Roberts, K. The Lovemarks Effect, Winning the Consumer Revolution; PowerHouse Books: New York; NY, USA, 2006.

41. Ghodeswar, B.M. Building brand identity in competitive markets: A conceptual model. JPBM 2008, 17, 4-12.

42. Gladwell, M. The Tipping Point: How Little Things Can Make a Big Difference; Time Warner Book Group: New York, NY, USA, 2000.

43. Berger, R.; Chambwera, M. Beyond Cost-Benefit: Developing a Complete Toolkit for Adaptation Decisions; IIED: London, UK, 2010.

44. Scheffer, M.; Bascompte, J.; Brock, W.A.; Brovkin, V.; Carpenter, S.R.; Dakos, V.; Held, H.; van Nes, E.H.; Rietkerk, M.; Sugihara, G. Early-warning signals for critical transitions. Nature 2009, 461, 53-59.

45. The Structure and Dynamics of Networks; Newman, M., Barabási, A-L., Watts, D.J., Eds.; Princeton University Press: New Jersey, NY, USA, 2006.

46. Erdós, P.; Rényi, A. On the evolution of randam graphs. In Publications of the Mathematical Institute of the Hungarian Academy of Sciences; Mathematical Institute of the Hungarian Academy of Sciences: Budapest, Hungary, 1960; pp. 17-61. 
47. Broder, A.; Kumar, R.; Maghoul, F.; Raghavan, P.; Rajagopalan, S.; Stata, R.; Tomkins, A.; Wiener, J. Graph structure in the Web. Computer Networks 2000, 33, 309-320.

48. Watts, D.J.; Strogatz, S.H. Collective dynamics of 'small-world' networks. Nature 1998, 393, 440-442.

49. Bianconi, G.; Barabási, A.L. Competition and multiscaling in evolving networks. Europhys. Lett. 2001, 54, 436-442.

50. Solé, R.V.; Pastor-Satorras, R.; Smith, E.; Kepler, T.B. A model of large-scale proteome evolution. Adv. Complex Syst. 2002, 5, 43-54.

51. Hao, H.; Wang, X. Spatial Planning for Climate Change Adaptation-Test and Improve Spatial Planning Methodology for the CCA. BSc-Thesis, Van Hall Larenstein, Wageningen, The Netherlands, 2010.

52. Broersma, S.; Fremouw, M.; Stremke, S.; van den Dobbelsteen, A.; de Waal, R. Duurzame Energiestructuurvisie Voor de Veenkoloniën; TU Delft/WUR: Delft, The Netherlands, 2011.

(C) 2012 by the authors; licensee MDPI, Basel, Switzerland. This article is an open access article distributed under the terms and conditions of the Creative Commons Attribution license (http://creativecommons.org/licenses/by/3.0/). 
Copyright of Sustainability (2071-1050) is the property of MDPI Publishing and its content may not be copied or emailed to multiple sites or posted to a listserv without the copyright holder's express written permission. However, users may print, download, or email articles for individual use. 